\title{
In Memoriam... dr hab. Robert Piotrowski (1965-2014)
}

2 kwietnia 2014 roku Instytut Filozofii Uniwersytetu Zielonogórskiego poniósł ciężką stratę - zmarł dr hab. Robert Piotrowski, pracownik Zakładu Logiki i Metodologii Nauk.

Studia magisterskie odbył na Uniwersytecie Warszawskim. Przez trzy lata studiował na Wydziale Fizyki, jednak magisterium uzyskał w Instytucie Filozofii w roku 1992. W semestrze letnim 1992/1993 przebywał na stypendium w zakresie antropologii kulturowej w Onderzoeksschool voor Sociale Wetenschap Uniwersytetu Amsterdamskiego.

Po kilkuletnim zatrudnieniu w Głównym Urzędzie Statystycznym podjął pracę w warszawskiej Wyższej Szkole Pedagogicznej TWP, gdzie był zatrudniony w latach 1998-2005. W tym czasie obronił w Instytucie Filozofii Uniwersytetu Śląskiego doktorat Antropologiczne perspektywy filozofii Tomasza Hobbesa (1998). Dysertacja została opublikowana w rozszerzonej formie jako książka Od materii Świata do materii Państwa. Z filozofii Tomasza Hobbesa (2000).

W latach 2002-2006 pracował jako adiunkt w Ośrodku Studiów Amerykańskich UW. Prowadził tam seminarium magisterskie oraz kursy tematyczne związane z filozofią amerykańską. Były to: filozofia amerykańska, antropologia kulturowa, amerykańska tradycja okultystyczna, amerykański spór o rasę i rasizm, osoba w filozofii amerykańskiej, spór ewolucjonizm-kreacjonizm. Prowadził też ogólnouniwersyteckie wykłady z logiki i z semiotyki. W roku 2003 wydał monografię Problem filozoficzny ladu społecznego a porównawcza nauka 
o cywilizacjach, zaś dwa lata później podręcznik Logika elementarna dla szkół akademickich.

Od roku 2007 pracował jako adiunkt w Zakładzie Logiki i Metodologii Nauk Instytutu Filozofii Uniwersytetu Zielonogórskiego. Prowadził tam zajęcia z filozofii anglosaskiej, filozofii niemieckiej, filozofii przyrody, metodologii nauk, klasycznej filozofii muzułmańskiej oraz filozoficznych aspektów okultyzmu zachodniego. Wydał też monografię Demon Maxwella. Dzieje i filozofia pewnego eksperymentu (2011), na podstawie której habilitował się w 2013 roku na Katolickim Uniwersytecie Lubelskim.

Czterokrotnie (w 2001, 2002, 2006 i 2008 roku) wyjeżdżał na krótkie pobyty w ramach programu ERASMUS (na Uniwersytet Macedoński w Salonikach, Uniwersytet Strathclyde w Glasgow, Uniwersytet we Frankfurcie nad Menem i Uniwersytet w Halle).

Uczestniczył w ponad 60 konferencjach i seminariach naukowych (w tym kilkunastu zagranicznych: w Danii, Niemczech, Anglii i na Ukrainie), podczas większości z nich wygłaszając referaty lub komunikaty. Między innymi dwukrotnie (w 2008 i 2009 roku) wyjeżdżał na konferencje do Ian Ramsey Centre Wydziału Teologii Uniwersytetu Oksfordzkiego („God, Nature and Design” oraz „Religious Responses to Darwinism 1859-2009”) i raz do Merton College na XVIII konferencję European Society of the Philosophy of Religion (,Religion in the Public Sphere", 2010). W roku 2000 uczestniczył w IV East-West American Studies Conference pt. „Communism, Capitalism, and the Politics of Culture" (Uniwersytet im. Goethego we Frankfurcie nad Menem). Dwukrotnie wyjeżdżał też na konferencje organizowane przez Program Filozofii przy School of Advanced Study Uniwersytetu Londyńskiego (w 1998 i 1999 roku). W roku 2011 został zaproszony z wykładem o dziewiętnastowiecznym fizykalizmie na warsztaty „The Relation(s) Between Physics and Metaphysics in the Nineteenth Century" (Uniwersytet Gandawski), na które jednak nie mógł wyjechać ze względu na stan zdrowia.

Od roku 2007 uczestniczył w konferencjach dotyczących filozofii siedemnastego wieku organizowanych corocznie w głównych ośrodkach filozoficznych w Polsce (KUL, UG, UMCS, UMK). Od roku 1997 wyjeżdżał na spotkania in- 
terdyscyplinarne zapoczątkowane przez prof. Andrzeja Wiercińskiego na ówczesnej Akademii Świętokrzyskiej. Dwukrotnie (w 2007 i 2010 roku) uczestniczył w seminariach historyków filozofii polskiej (KUL, UJ). W roku 2007 wziął udział w konferencji „Pogranicza nauki: Protonauka - paranauka - pseudonauka”, a w roku 2009 w konferencji „Transfer idei. Od ewolucji w biologii do ewolucji w astronomii i kosmologii" (KUL, wystąpienia zostały opublikowane w t. 3 i 7 serii Filozofia przyrody i nauk przyrodniczych). Trzykrotnie (w 2006, 2007 i 2008 roku) uczestniczył w konferencjach na temat zrównoważonego rozwoju organizowanych przez Komitet „Człowiek i Środowiska” przy Prezydium PAN i Politechnikę Lubelską. Z pojedynczych konferencji warto wymienić „Ideę kreacji we współczesnej filozofii i nauce” (UMCS, 2005) i „Filozofię przyrody współcześnie” (UMCS, 2008).

Zainteresowania naukowe Roberta Piotrowskiego obejmowały szeroko pojętą fillozofię kultury, historię filozofii anglosaskiej, szczególnie nowożytnej, historię filozofii polskiej od końca dziewiętnastego wieku, logikę stosowaną, filozofię fizyki i ewolucjonizm. Ostatnio zajmował się filozoficznymi aspektami podstaw cybernetyki oraz fizykalizmem przełomu dziewiętnastego wieku. Najważniejsze prace naukowe Roberta Piotrowskiego to w porządku chronologicznym:

- analiza filozofii Hobbesa;

- analiza filozoficzna i częściowa rekonstrukcja porównawczej teorii cywilizacji;

- analiza doktryny inteligentnego projektu w aspekcie kulturowym;

- opracowanie filozoficzno-historyczne paradoksu demona Maxwella.

Pisząc o filozofii Hobbesa, skupił się na jego antropologii filozoficznej, przedstawiając ją na tle mechanistycznej metafizyki oraz, ogólniej rzecz biorąc, mechanizacji światopoglądu nowożytnego. Przedstawił między innymi własną interpretację Hobbesowskiego stanu natury, pojęcia czasu w jego filozofii oraz związku między fizyką a antropologią z podkreśleniem roli conatus-endeavour, a także inną od ogólnie przyjmowanej klasyfikację całego systemu Hobbesa.

Porównawcze teorie cywilizacji analizował na podstawie prac Feliksa Konecznego i Erazma Majewskiego. Częściową rekonstrukcję systemu Koneczne- 
go oparł na najbardziej interesujących według niego jej składowych, a szczególnie ciągach cywilizacyjnych, dualizmie energii, kwinkunksie (pięciomianie cywilizacyjnym), naczelnych szeregach pojęć, ,prawach dziejowych” oraz wyróżnikach cywilizacyjnych. Podkreślał zbieżność idei polskiego historiozofa z pomysłami pisarzy angielskich: Spencera, T.S. Eliota i kardynała Newmana (u tego ostatniego występują ,prawa rozwoju idei” w pewnym stopniu analogiczne do „praw dziejowych”). Postawił pytanie, co faktycznie było pozytywnym wkładem Konecznego w rozwój teorii cywilizacji, uznając, iż najważniejsze było ujęcie tak struktury cywilizacji, jak i kontaktów międzycywilizacyjnych z perspektywy logicznej niesprzeczności oraz rozwiązanie kwestii relacji kultury i religii. W związku z tym ostatnim wskazał na szczególną rolę religii oraz cywilizacji sakralnych (to jest formacji kulturowych całościowo generowanych przez religię), do których sam Koneczny odnosił się w sposób nacechowany jednocześnie niechęcią i fascynacją. Opisał niedostatki doktryny Konecznego (nie wszystkie, oczywiście, zawinione przez jej twórcę), jednym z nich jest niemal zupełny brak analizy procesu powstawania cywilizacji, szczególnie wobec wnikliwego rozważenia ich degeneracji i upadku. Przedstawił możliwość zastosowania metod taksonomicznych do Koneczniańskiej kombinatoryki cywilizacyjnej, porównał też doktrynę Konecznego z reklamowaną ostatnio koncepcją Huntingtona.

Piotrowski systematycznie zestawił też teorię Majewskiego z teorią Konecznego oraz ujawnił jej osobliwości formalne. Doktryna Konecznego opiera się na dystrybutywnym, zaś Majewskiego na kolektywnym pojmowaniu społeczności. Ponadto u Majewskiego wskazał na interesującą hierarchię indukcyjną kolektywów przyrodniczych, której szczeblem jest cywilizacja.

Sprawa doktryny inteligentnego projektu (IP) zainteresowała Roberta Piotrowskiego jako przykład konfliktu światopoglądowego na tle antagonistycznych relacji kreacjonizmu i doktryn pokrewnych z szeroko pojętym ewolucjonizmem. Jak wiadomo, konflikt ów wynikł z recepcji ewolucjonizmu w świecie anglosaskim, jednak z logicznego punktu wcale nie był nieuchronny, przeciwnie — ewolucjonizm i kreacjonizm są teoretycznie jak najbardziej do pogodzenia. Tym ciekawsze jest, dlaczego konflikt ten faktycznie wystąpił, a obecnie mamy wręcz do czynienia z oznakami jego intensyfikacji. Piotrowski scharakteryzował leksykon i podstawowe koncepcje IP na tle ogólnego schematu relacji nauki 
z religią oraz ewolucjonizmu z kreacjonizmem, poruszając też kwestie przyczyn historycznej niestabilności kreacjonizmu wobec ekspansywności ewolucjonizmu; roszczeń kreacjonistów do objęcia ich poglądów „tolerancją”; systematycznego porównania poszczególnych konkretyzacji ewolucjonizmu (doktryn „transformistycznych”).

Rozprawa habilitacyjna Roberta Piotrowskiego dotyczyła demona Maxwella. Stanowi on, jego zdaniem, jeden z najciekawszych i najważniejszych eksperymentów myślowych w historii fizyki. Polega na wyobrażeniu sobie czynnika, który na poziomie molekularnym sortuje molekuły gazu ze względu na kierunek lub prędkość ich poruszania się. Taki demon miałby ostatecznie wytwarzać nierównowagę ciśnienia lub temperatury w układzie znajdującym się początkowo w stanie równowagi termodynamicznej. A to z kolei oznaczałoby sprzeczność $\mathrm{z}$ drugim prawem termodynamiki, zatem pojawiłby się niezwykle istotny paradoks sięgający podstaw jednej z najważniejszych dziedzin fizyki. Autor rozprawy przedstawił historię i filozofię demona Maxwella w sposób interdyscyplinarny, rzecz jasna głównie w kontekście samej fizyki, ale również biologii, humanistyki i ekonomii. Opisał kontekst oryginalnej koncepcji Maxwella i scharakteryzował demona według obecnych kryteriów jako nieudany eksperyment destruktywny, choć z drugiej strony wskazał, że jak na okazjonalnie rzucony pomysł, demon okazał się całkiem silnym impulsem rozwoju fizyki statystycznej i termodynamiki. Systematycznie porównał najważniejsze rozwiązania paradoksu demona oraz wskazał na zmienny kontekst kolejnych analiz: od względnie wczesnej fazy rozwoju termodynamiki aż do współczesności. Można je podsumować tak, że w trakcie swojej historii demon Maxwella uległ metamorfozie $\mathrm{z}$ mechanizmu $\mathrm{w}$ proces obliczeniowy. Piotrowski przedstawił skonstruowane ostatnio rzeczywiste urządzenia, których działanie nie przeczy drugiej zasadzie, ale które były niewątpliwie inspirowane koncepcją demona. Opisał także jego „żywot pozafizyczny”, nie tylko w biologii, ale również w dziedzinach od fizyki całkiem odległych, jak literatura i ekonomia.

Robert Piotrowski był też bliskim współpracownikiem Zielonogórskiej Grupy Lokalnej „Nauka a Religia”, jak również prowadzonego przez nią czasopisma internetowego Filozoficzne Aspekty Genezy. 